\title{
IV. RESPONSE OF CITRIC ACID LEVELS OF NORMAL ADULTS AND CHILDREN TO INTRAMUSCULAR INJECTION OF EPINEPHRINE ${ }^{1}$
}

\author{
By JOSEPH B. PINCUS, SAMUEl NATELSON, and JUliUS K. LUGOVOY \\ (From the Pediatric Rescarch Laboratory and the Department of Biochemistry of the Jewish \\ Hospital of Brooklyn)
}

(Received for publication December 22, 1948)

Our earlier observations that oral administration of glucose would cause a lowering of citric acid levels in humans $(1,2)$ led us to investigate the effect of epinephrine on citric acid levels.

One-half minim of a $0.1 \%$ solution of epinephrine in water per kilogram of body weight was administered with a maximum dose of ten minims to any individual, after a 12-hour fasting period. Thus all adults and most children studied received a dose of 10 minims intramuscularly. Serum glucose and citric acid levels were followed at short intervals as shown in the charts below. In view of the varying response of different individuals, average curves were not drawn but representative results are shown in Figure 1 for children, and Figure 2 for adults. Glucose determinations were carried out by the method of Folin and $\mathrm{Wu}$ (3) and citric acid determinations were carried out as described before (4). This latter method has been in routine use in our laboratory for more than a year and is in error by less than $5 \%$.

Comparison of fasting serum levels of citric acid with the maximum level reached after epinephrine administration is tabulated in Table I. Results obtained on the serum of children and adults are averaged together since no significant difference was noted between the two groups.

TABLE I

Comparison of fasting serum levels of citric acid with citric acid levels obtained after epinephrine administration

\begin{tabular}{c|c|c|c|c}
\hline \hline No. cases & $\begin{array}{c}\text { Average } \\
\text { fasting } \\
\text { level }\end{array}$ & $\begin{array}{c}\text { Average } \\
\text { maximum } \\
\text { level }\end{array}$ & $\begin{array}{c}\text { \% increase } \\
\text { over fasting } \\
\text { level }\end{array}$ & $\begin{array}{c}P \text { value } \\
\text { fasting vs. } \\
\text { max. level }\end{array}$ \\
\hline \multirow{3}{*}{28} & $\begin{array}{c}m g . \% \\
2.16\end{array}$ & $\begin{array}{c}m g . \% \\
2.85\end{array}$ & 32 & $5 \times 10^{-5}$ \\
\hline
\end{tabular}

In order to compare these results with the effect of insulin, similar studies were carried out with insulin administered intramuscularly. This type of study had been reported before but no curves

1 Presented at the Meeting of the American Chemical Society at Washington, D. C., August 30, 1948. were shown (1): Figure 3 shows four typical curves obtained in this study.

We have also studied the effect, on citric acid levels, of intravenous administration of glucose (5). Figure 4 shows a typical result obtained after the intravenous administration of glucose to a 100 lb. girl ( $50 \mathrm{mg} . / \mathrm{lb}$.). A total of 5 grams of glucose dissolved in $25 \mathrm{ml}$. of water was administered within a one-minute period. This curve is included for comparison with the curves obtained on intramuscular administration of epinephrine.

\section{DISCUSSION}

It can be seen readily from Figures 1 and 2, and Table I that intramuscular injection of epinephrine will cause a rise in citric acid serum levels. This is in contradistinction to the effect of insulin (Figure 3 ) or glucose, either orally $(1,2)$ or intravenously (Figure 4), all of which cause a lowering of citric acid levels.

Earlier (2) we reported that certain convulsives and diabetics responded to administration of glucose with a rise in citric acid levels rather than a fall. We are investigating the possibility that in these cases some abnormality exists which results in excessive epinephrine secretion during the test.

A preliminary drop in citric acid levels, from the fasting level, was observed in 17 out of the 28 cases. The average citric acid level for all cases, $15 \mathrm{~min}$ utes after the administration of epinephrine, was $3 \%$ lower than the fasting level. Statistical comparison of this level with the fasting level yielded a $P$ value of 0.6 which is not statistically significant. Thus it can be said that no significant rise in citric acid levels occurs within the first 15 minutes. The rise in glucose levels during this time (within 15 minutes) is definitely significant, being $50 \%$ higher than the fasting level. Compar- 
RESPONSE OF CITRIC ACIO ANO GLUCOSE LEVELS TO INTRAMUSCULAR ADMINISTRATION OF EPINEPHRINE (NORMAL CHILOREN)

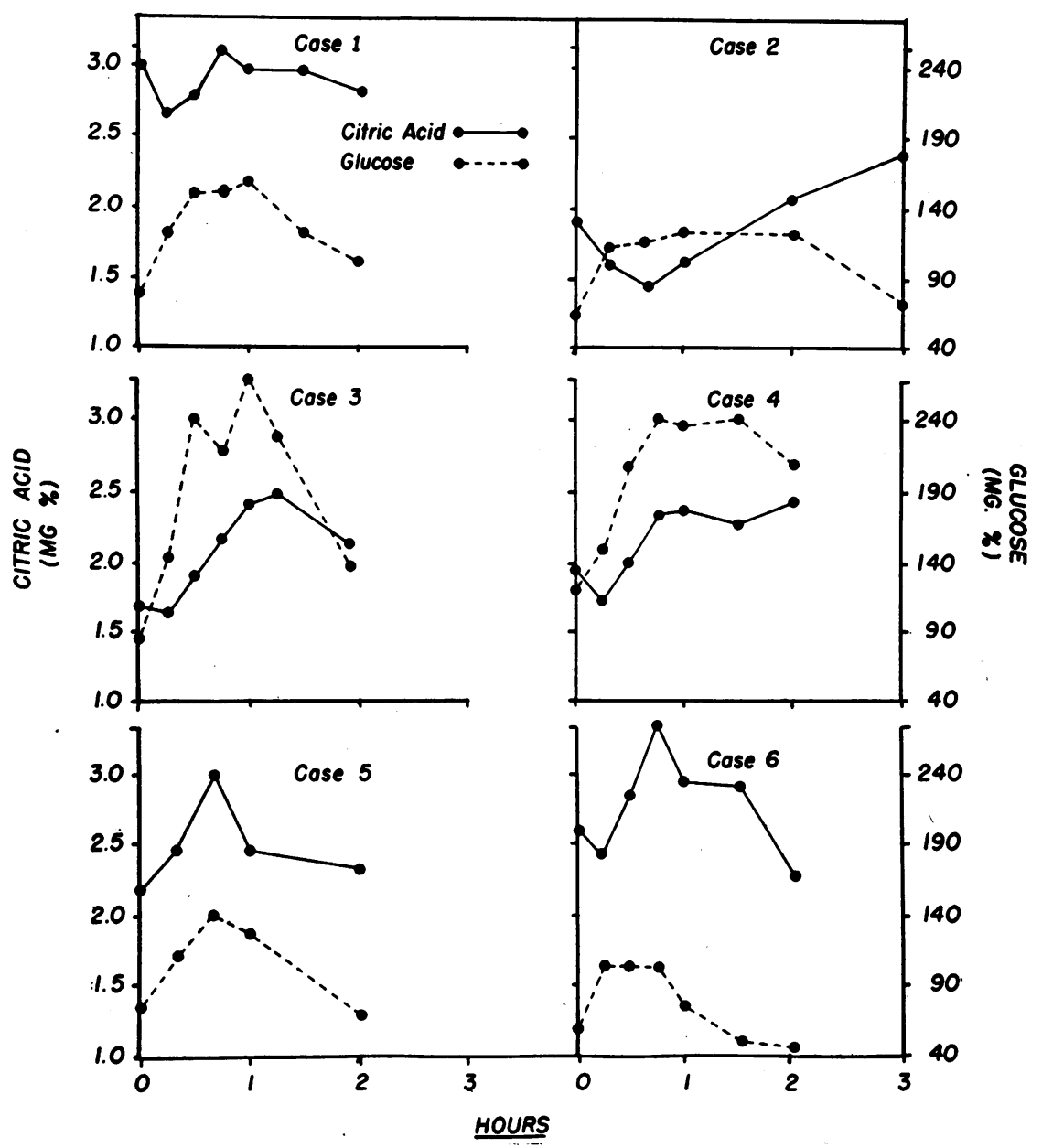

Fig. 1. Representative Curves Illustrating the Effect of Intramuscular Injection of 0.5 Minims/Kilo of Epinephrine on Serum Citric Acid and Glucose Levels (Normal Children)

ing this level with the fasting level a $P$ value of $10^{-7}$ is obtained. Thus the response in changes of glucose levels on administration of epinephrine is more rapid than the response of citric acid levels. These observations would imply that the action of epinephrine, in its effect on citric acid levels, is probably more indirect than the mechanism whereby it acts in causing a rise in serum glucose levels.

Other acids like pyruvic and lactic acids which are intermediates in glucose metabolism increase when glucose, insulin or epinephrine is administered $(6-12)$. However, the literature is not in complete agreement as to the effects of insulin and glucose administration on serum lactic acid levels (13).

Citric acid is distinctive in showing a lowering of the serum levels on the administration of insulin or glucose but a rise on administration of epinephrine.

The observation that epinephrine will cause a rise in citric acid levels must be taken into account when explaining changes in citric acid levels under certain abnormal conditions. For example, Lövgren claims that high citric acid levels are found consistently in acute allergic states (14). 
This may be associated with an increase in epinephrine secretion observed in this condition (15).

Other substances have been reported as causing increased citric acid levels in the blood. Alwall (16) reports an increase in citric acid levels with prostigmine in man. However, Martensson (17) disagrees with these findings and reports no change. Differences of this type which appear in the literature may be due, in part, to variations in the alarm response of patients under the varying conditions under which the experiments were carried out.

Physostigmine, a compound related in physiological action to prostigmine, is reported to interfere with a rise in citric acid levels which normally follows injection of calcium lactate (18). The action of this drug and others like it which lower citric acid levels should be studied in their rela- tionship to their anti-epinephrine action and their effect on epinephrine secretion.

Of interest is the observation of Hajdu and Korenyi (19) that continuous injection of citric acid will cause hypertrophy of the medulla of the suprarenals. If the left celiac ganglion is extirpated hypertrophy does not occur. The greatest concentration of citric acid in the body occurs in the suprarenals (20-22).

Synthalin, a guanidine derivative, causes a lowering of glucose levels in diabetics. This compound and guanidine itself will produce a rise in citric acid levels when injected (23). In view of our observations that insulin causes a lowering of citric acid levels, it is apparent that synthalin, as far as its effect on citric acid levels is concerned, is quite different from insulin. It is well known that synthalin produces liver damage (24-26). In

RESPONSE OF CITRIC ACID ANO GLUCOSE LEVELS

TO INTRAMUSCULAR ADMINISTRATION OF EPINEPHRINE (NORMAL AOULTS)

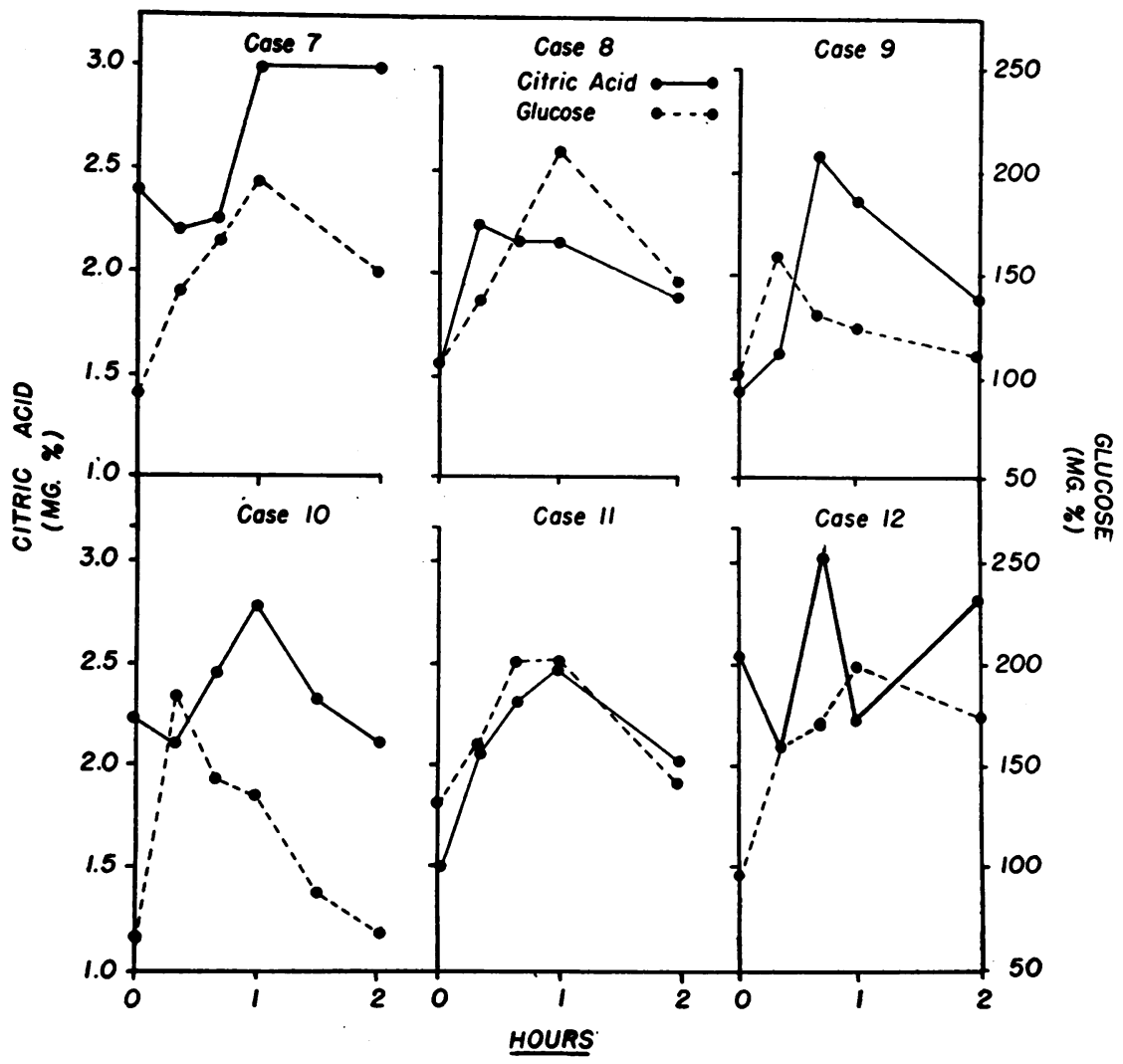

Fig. 2. Representative Curves Illustrating the Effect of Intramuscular Injection of 0.5 Minims/Kilo of Epinephrine on Serum Citric Acid and Glucose Levels (Normal Adults) 
RESPONSE OF CITRIC ACIO ANO GLUCOSE LEVELS TO INTRAMUSCULAR ADMINISTRATION OF INSULIN (NORMAL AOULTS)

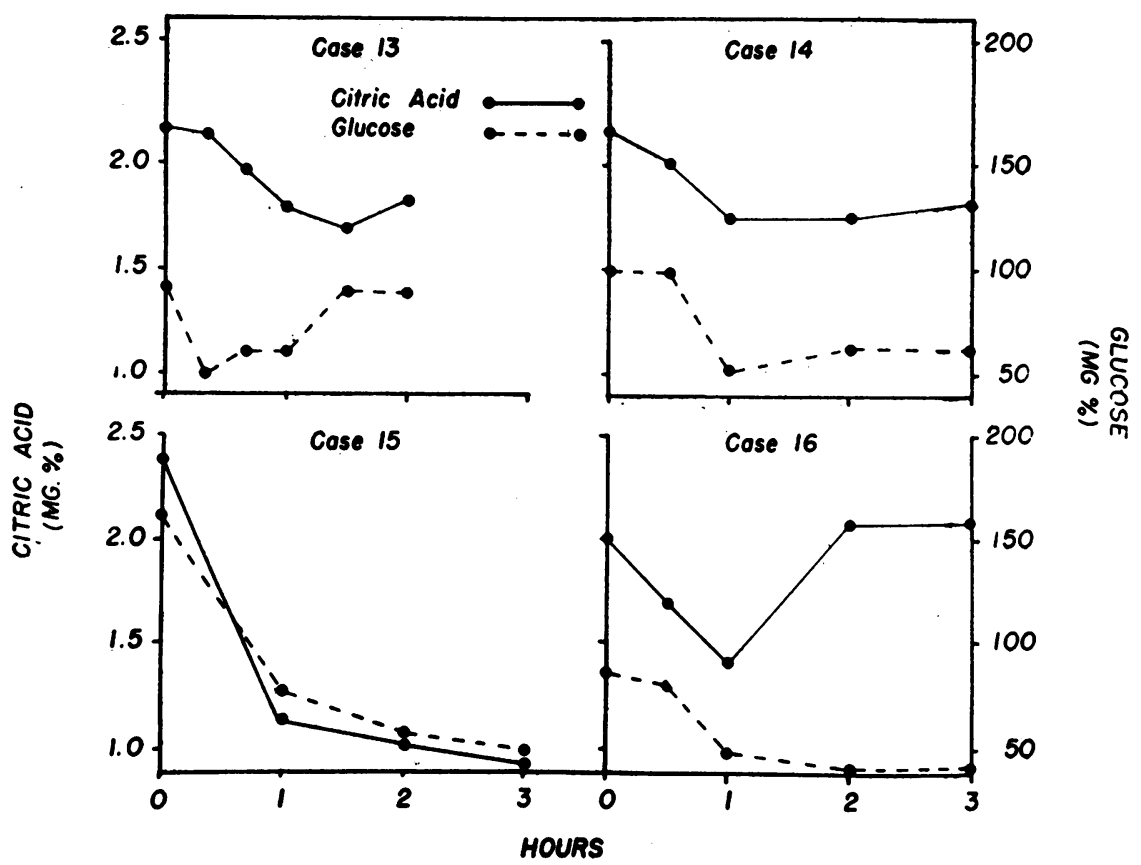

Fig. 3. Representative Curves Illustrating the Effect of Intramuscular Injection of Insulin ( $1 / 2$ Unit/Kilo) on Serum Citric and Glucose Levels

RESPONSE OF CITRIC ACID AND GLUCOSE LEVELS TO INTRAVENOUS ADMINISTRATION OF GLUCOSE

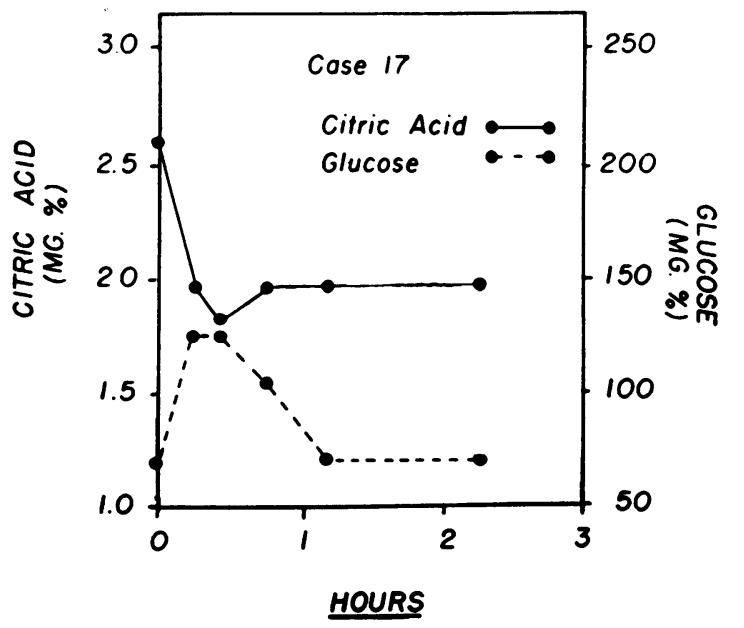

Fig. 4. Changing Serum Citric Acid and Glucose LeVels after INTRAMUSCUlar InJection of 50 Mg./ LB. OF Glucose severe liver damage elevated citric acid levels have been reported (27).

The exact relationship between citric acid and endogenous epinephrine levels will be ascertained only when a precise and specific method for the determination of minute amounts of epinephrine becomes available.

\section{SUM MARY}

Epinephrine administered intramuscularly caused a rise in citric acid serum levels in 28 normal adults and children.

Administration of glucose intravenously or insulin intramuscularly results in a decrease in citric acid serum levels.

\section{BIBLIOGRAPHY}

1. Natelson, S., Pincus, J. B., and Lugovoy, J. K., Response of citric acid levels to oral administration of glucose. I. Normal adults and children. J. Clin. Invest., 1948, 27, 446.

2. Pincus, J. B., Natelson, S., and Lugovoy, J. K., Response of citric acid levels to oral administration 
of glucose. II. Abnormalities observed in the diabetic and convulsive state. J. Clin. Invest., 1948, 27, 450.

3. Folin, O., Two revised copper methods for blood sugar determinations. J. Biol. Chem., 1929, 82, 83.

4. Natelson, S., Pincus, J. B., and Lugovoy, J. K., Microestimation of citric acid, a new colorimetric reaction for pentabromacetone. J. Biol. Chem., 1948, 175, 745.

5. Gottfried, S. P., Pincus, J. B., Natelson, S., and Lugovoy, J. K., Response of serum citric acid levels to massive injection of insulin in schizophrenics. J. Mental Disease, 1949. In press.

6. Shcherbatskaya, V. A., Distribution of pyruvic acid between plasma and blood corpuscles. I. Injection of glucose, adrenaline and insulin in dogs. Biokhimiya, 1939, 4, 10.

7. Griffith, F. R., Jr., Lockwood, J. E., and Emery, F. E., Adrenalin lactacidemia: proportionality with dose. Am. J. Physiol., 1939, 127, 415.

8. Razzo, M., Lactic acid of the blood after adrenaline injections in persons with liver disorders. Boll. Soc. ital. biol. sper., 1945, 20, 137.

9. Collazo, J. A., and Almela, J., Insulin and lactic acid in blood. Ann. de méd., 1935, 38, 371.

10. Neiman, F. I., and Sokolow, A. U., The relation of pulmonary tissue of dogs to sugar and lactic acid after intravenous injection of insulin. Bull. biol. et méd. Exper. URSS, 1940, 9, 491.

11. Erben, F., Carbohydrate metabolism in glycogenesis. Ztschr. f. Klin. Med., 1938, 134, 31.

12. Gillman, T., and Goldberg, L., Investigations on blood pyruvic acid. II. The effects of administering glucose, insulin and adrenaline on blood pyruvic acid in normal human adults. South African J. M. Sc., 1943, 8, 156.

13. Baisset, A., Bugnard, L., and Rogeon, J., Lactic acid content of blood. Bull. Soc. Chim. Biol., 1938, 20, 51.

14. Lövgren, O., The intermediate metabolism in chronic polyarthritis. Acta med. Scandinav., Supp., 1945, 163.
15. Smanyi, G., and Zimanyi, I., The determination of adrenaline in blood during allergic reactions. Magyar Orvosi Arch., 1939, 40, 429.

16. Alwall, N., The regulation of the citric acid content of the blood. I. Influence of autonomic drugs on the serum citric acid content in man as well as in normal and nephrectomized rabbits. Acta med. Scandinav., 1942, 110, 476.

17. Martensson, J., Effect of prostigmine on the citric acid content of serum. Acta med. Scandinav., 1946, 126, 254.

18. Alwall, N., Studies on the regulation of citric acid content of blood serum. V. Relation between calcium and citric acid in serum. Acta med. Scandinav., 1945, 122, 448.

19. Hajdu, I., and Korenyi, Z., The volume changes of the suprarenal cortex and medulla in exercise and after injection of certain substances. Arch. internat. de pharmacodyn. et de thérap., 1942, 67, 373.

20. Viale, G., Citric acid in the adrenals. Biochim. e Terap. Sper., 1934, 21, 103.

21. Viale, G., Citric acid in the suprarenal capsules. Problemes Biol. Med. Moscow, 1935, 600.

22. Slate, W. L., Report of the director for the year ending Oct. 31, 1944. Agr. Expt. Sta. Bull., 1945, 484, 103.

23. Martensson, J., Effect of guanidine and synthalin on the citric acid metabolism. Acta med. Scandinav., 1946, 125, 82.

24. Varela, B., Collazo, J. A., and Rubino, P., Experimental toxicity of polymethylene derivatives of guanidine. Compt. Rend. Soc. de Biol., 1928, 99, 1444.

25. Hornung, S., Synthalin and liver injury. Klin. Wchnschr., 1928, 7, 69.

26. Karr, W. G., Belk, W. P., and Petty, O. H., Toxicity of synthalin. J. Pharmacol. \& Exper. Therap., 1929, 36, 611.

27. Sjöstrom, P., Citric acid in the blood serum in the diagnosis of the diseases of the liver and bile ducts. A methodological, experimental and clinical study. Acta chir. Scandinav., Supp., 1937, 49, pp. 238. 